\title{
Analysis of a dimensional tolerances' series of 2PW-SE gear pumps using multi valued logical trees
}

\author{
Adam Deptuła ${ }^{1, *}$, Piotr Osiński², and Marian A. Partyka ${ }^{1}$ \\ ${ }^{1}$ Opole University of Technology, Faculty of Production Engineering and Logistics, Poland \\ ${ }^{2}$ Wroclaw University of Science and Technology, Faculty of Mechanical Engineering, Poland
}

\begin{abstract}
Gear pumps of a prototype series 2PW-SEW belonging to II group were the research object. Wrocław University of Technology in co-operation with the company HYDROTOR S.A. designed the units. The experimental pump has been designed with taking into consideration technological possibilities of the company HYDROTOR S.A. The innovation of the prototype unit is based on using oblique gears with an involute tooth modified in the lower and upper part of the profile. The modification in the lower part was made using the so-called tooth root undercutting. Multivalent logic trees with designated rank of importance parameters structural/operational were used, considering the effect of tolerances construction. The area has been increased by cutting the oblique teeth. In order to determine the influence of the manufacturing technology on the level of the emitted noise, it has been decided to make gears using the shaving technology.
\end{abstract}

\section{Introduction}

Hydraulic systems are being increasingly used because of the high-power transmission capabilities with relatively high efficiency. The first industrial application of pumps dates back to the 15 th century, when they were used to drain mines. A positive displacement pump was mentioned in 1604; it was a German astronomer's pump patent and mathematics of Johannes Kepler (1571-1630). The original application of the reserved solution at the time was to pump water into drained mines $[1,2,3]$. Currently, a variety of different construction solutions are used. Of the group of positive displacement pumps, gear pumps with external gearing are mostly applied. Pumps of this type are characterised by relatively high working pressures up to 32MPa. For this purpose, axles of gears are mounted with a predetermined clearance and loaded with radial force acting on the divided bearing bodies. Production of gears with zero lateral play requires a high technological regime $[4,5,6]$.

Currently, pumps are among the most widespread working machines and are used in all fields of technology. Among the positive displacement pumps used in hydraulic propulsion systems as energy generators, gear pumps are the most widespread. Their participation is estimated at more than half of all pumps manufactured. Such common use results from a simple and compact design, operational reliability, high efficiency factor and low production cost. Development of modern pumping units is currently associated with two trends: minimisation of mass, vibrations, pulsation of efficiency and reduction of noise emission to the environment $[7,8,9,10]$. The improvement of internal tightness is connected with minimisation of energy losses, increasing the transferred power and energy efficiency of the generator [11, 12]. The use of pumps in hydraulic systems is of particular importance, especially as a source of mechanical vibrations [13, 14]. An important source of vibrations are propulsion systems, e.g. a combustion engine performing periodic work cycle with variable characteristics. The working hydraulic system is also a source of mechanical vibrations caused mainly by shock pressure changes, periodic character of displacement pump operation. Vibrations generated in this way are characteristic at different frequencies, so there are different ways to transfer them [5]. The problem also applies to micropumps [15]. The total efficiency of gear pumps which are produced nowadays is equal to about $80-90 \%$ (for nominal pressured reaching $28 \mathrm{MPa}$ ). Such a large span is mainly connected with the adopted manufacturing tolerance.

\section{The optimisation of three-involute tooth outline}

The purpose of the identification of the impact of the technology of construction of polyvalent pump construction was an attempt to determine the sensitive control dimensions (values/tolerances) of tested pumps for teeth made in chip technology [16] and grinding [17], [18] and [19]. Control dimensions concerned six details of the pump data: the raking gear, the driven gear, the set of bearings, the body, the plate, the cover and the tightening force of the screws. Tests carried out for 40 units of model and prototype pumps showed that it was not possible to analyse only selected details, e.g. gear wheels, for the overall efficiency of the gear pump. The analysis first employed a heuristic method based on local

* Corresponding author: a.deptula@po.opole.pl 
searching of the largest deviations between data values $[20,21]$. Then, an algorithm of induction of decision trees based on the growth of entropy was applied [22, 23]. A neural network was implemented - learning measurement relationships between data, finding the most important control points [24, 25].

The first publication cycle concerned the application of the multi-valued logical tree method. In work [8], multi-valued logical trees were used to determine the sensitivity of measuring points for (3PWR-SE) model pumps. The work [26] described type 2PWR-SE model pumps. This article presents the results of the use of multivalent logic trees for the model pump number 2PW-SE [16] from the point of view of the criterion of total efficiency. The Quine-McCluskey algorithm of minimising the partial multivalent logic functions allows to use the tree structures as tools for application and support design process, optimisation and decisionmaking process [27]. If the design and/or operating parameters, hosting numeric values from a specific range, were designated by a set of logic variables, we can perform discretization of such numerical ranges. The set of all number combinations is a variants tree with the number of levels equal to the number of design and/or operational parameters.

\section{The research object}

Gear pumps of the prototype series 2PW-SEW belonging to II group $[6,16]$ were the research object. Wrocław University of Technology in co-operation with the company HYDROTOR S.A. designed aforementioned units. The experimental pump was designed taking into consideration technological possibilities of HYDROTOR S.A. The innovation of the prototype unit is based on oblique gears with involute teeth modified in the lower and upper part of the profile. The modification in the lower part was made using the so-called tooth root undercutting. The outline has an elongated shape in the normal plane and its application causes the shortening of a part of the buttress and decreasing of the sealed area. The area was increased by cutting the oblique teeth. The inclination of the tooth line also favours the decrease in the pressure pulsation $[9,10$, 15, 28] (Fig. 1).

Pumps prototype was entirely executed by the company HYDROTOR S.A. In the research, types of 10 gear pumps with serial numbers $2 \mathrm{PW}-\mathrm{SEW}-08-28$ $2-776$ with $q=8[\mathrm{~cm} \mathrm{3/rev]} \mathrm{were} \mathrm{used.}$

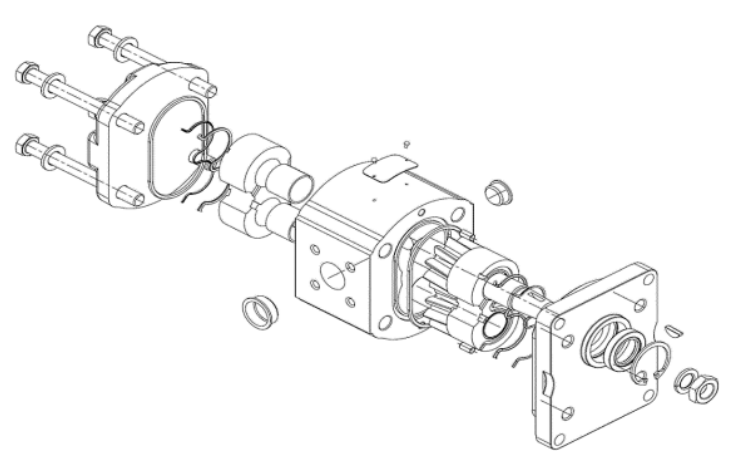

Fig. 1. The exploded view of the prototype gear pump type 2PW - SEW.
Based on our calculations and technological capabilities, Hydrotor SA (implementing entity structure) designed a whole range of gear pumps for involute. Then, the company developed the technology of a new outline. Before performing an optimised kinematics of the wheel, logic meshing three-involute profile on wheels printed in 3D was checked by polyvalent trees. The wheel model presented in Figure 2 was equivalent to wheels designed for pumps of the second group with a capacity of unit $q=8\left[\mathrm{~cm}^{3} / \mathrm{rev}\right]$

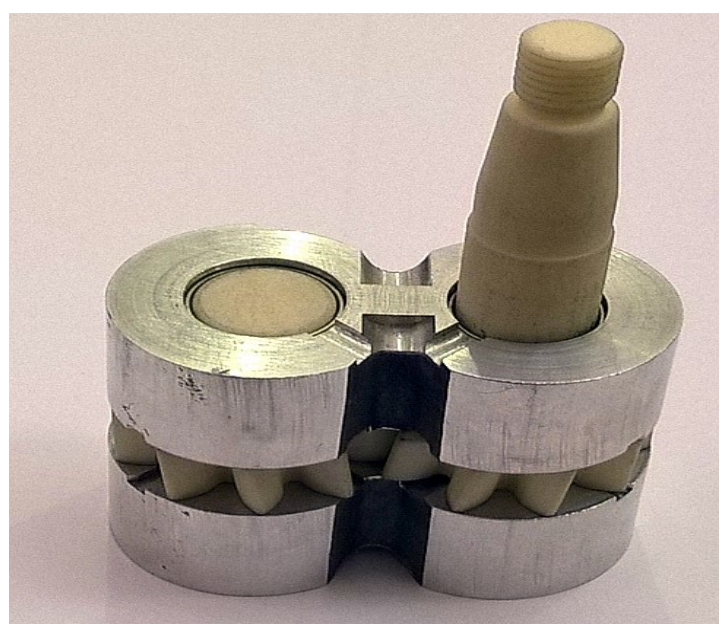

Fig. 2. Wheels three- involute made in 3D printing technology.

\section{Analysis of a dimensional tolerances' series of $2 \mathrm{PW}-\mathrm{SE}$ gear pumps using multi valued logical trees}

Control measurements (value/tolerance) for a gear pumps prototype series were the object of the analysis. The aim was to identify sensitive dimensions of the controls (value/tolerance) testing the pumps. Check dimensions of six pieces of data related to pumps: measurement of tightening $P D s$, active gear $K Z P$, passive gear $K Z P n$, a set of bearings $K L$ and $K L a$, corps $K R$, plate $P L t$, cover $P K r$. A correct evaluation of tolerance was especially important during construction of integrated decision-making methods. As a result of calculations, 23 most important control measurements and 56 less important measurements were obtained. Figure 3 shows the most important and less important example control points for the details: passive gear KZPn.

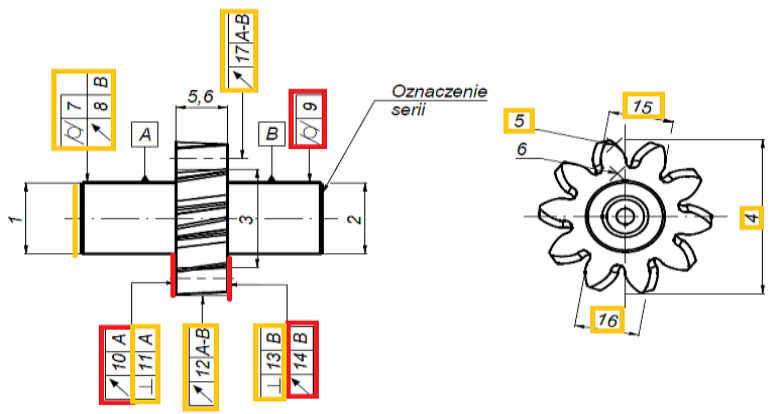

Fig. 3. The most important and less important control points for detail- passive gear KZPn 
The Figures 4-5 show an exemplary comparison of the efficiency of the total ten gear pumps $2 \mathrm{PW}-\mathrm{SEW}-08$ $28-2-776$ for $n=500$ and 2000 [rev $\mathrm{min}]$.

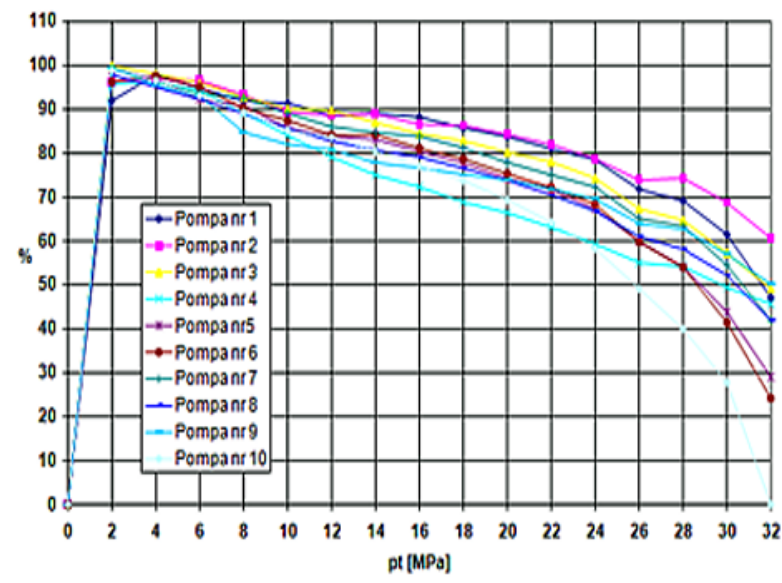

Fig. 4. Total efficiency $\eta_{C}$ gear pumps $2 \mathrm{PW}-\mathrm{SEW}-08-28-$ $2-776$ for $n=500$ [rev/min][16].

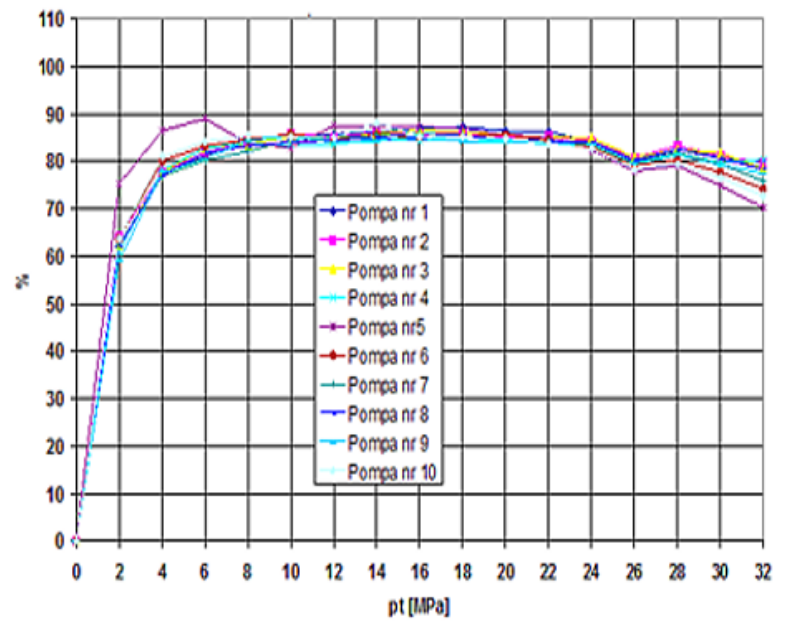

Fig. 5. Total efficiency $\eta_{C}$ gear pumps $2 \mathrm{PW}-\mathrm{SEW}-08-28-$ $2-776$ for $n=2000[\mathrm{rev} / \mathrm{min}]$ [16].

\subsection{The Quine-McCluskey algorithm of the minimisation of multiple- valued logic functions}

The Quine-McCluskey algorithm makes it possible to find all prime implicants of a given logic function, that is a shortened alternative normal form SAPN [29, 30]. The terms of incomplete gluing and elementary absorption have the main role in the search of prime implicants and are used for the APN of a given logic function. The following transformation is called the consensus operation:

$$
A j_{o}\left(x_{r}\right)+\ldots+A j_{m_{r}-1}\left(x_{r}\right)=A
$$

where: $r=1, \ldots, n$ and $A$ - a partial elementary product, the literals of which possess variables belonging to the set: $\left\{x_{1}, \ldots, x_{1}, x_{1}, \ldots, x_{n}\right\}$.

For example a multiple-valued logical function $f\left(x_{1}, x_{2}, x_{3}\right)$, where $x_{1}, x_{2}, x_{3}=0,1,2$, written by means of numbers KAPN (Canonical Alternative Normal Form): 100, 010, 002, 020, 101, 110, 021, 102, 210, 111, $201,120,022,112,211,121,212,221,122$, there is one
MZAPN (Minimal Complex Alternative Normal Form) after the application of the Quine-Mc Cluskey algorithm based on the minimisation of individual partial multivalued logical functions having 13 literals [29, 30].

$$
\begin{gathered}
f\left(x_{1}, x_{2}, x_{3}\right)=j_{o}\left(x_{1}\right)\left(j_{o}\left(x_{2}\right) j_{2}\left(x_{3}\right)+j_{1}\left(x_{2}\right) j_{o}\left(x_{3}\right)+j_{2}\left(x_{2}\right)\right)+ \\
\quad+j_{1}\left(x_{1}\right)+j_{2}\left(x_{1}\right)\left(j_{o}\left(x_{2}\right) j_{1}\left(x_{3}\right)+j_{1}\left(x_{2}\right)+j_{2}\left(x_{2}\right) j_{1}\left(x_{3}\right)\right) .
\end{gathered}
$$

\subsection{Application of multi-valued logic decision trees}

The values of arithmetic discharge pressure $P_{t}$ and a rotation speed $n$, considering the efficiency of the pumps model, were coded logic of the respective periods of the tables 1-2. Tables 3-4 show the specific and general logical coding for ranges of changes $P_{t}$ and $n$, in which at least 7 correspond pumps efficiency defined with a tolerance of $5 \%$ and exactly 10 pumps meet prescribed performance with a tolerance of $5 \%$.

Table 1. General and specific logical encoding for the full

\begin{tabular}{|c|c|c|c|c|c|c|c|c|c|c|c|c|c|}
\hline \multicolumn{2}{|c|}{$P_{t}$} & & $\begin{array}{l}2 \mathrm{PW} \\
\mathrm{nr} !\end{array}$ & $\begin{array}{l}2 \mathrm{PW} \\
\mathrm{n} \mathbf{2}\end{array}$ & $\begin{array}{l}2 \mathrm{PW} \\
\mathrm{nr} 3\end{array}$ & $\begin{array}{l}2 \mathrm{PW} \\
\mathrm{nr} 4\end{array}$ & $\begin{array}{l}2 \mathrm{PW} \\
\mathrm{n} \times 5\end{array}$ & $\begin{array}{l}2 \mathrm{PW} \\
\mathrm{nr} 6\end{array}$ & $\begin{array}{l}2 \mathrm{PW} \\
\mathrm{nr} ?\end{array}$ & $\begin{array}{l}2 \mathrm{PW} \\
\mathrm{nr} 8\end{array}$ & $\begin{array}{l}2 \mathrm{PW} \\
\mathrm{n}=9\end{array}$ & $\begin{array}{l}2 \mathrm{PW} \\
\mathrm{nr} 10\end{array}$ \\
\hline$c^{8}$ & $\mathrm{MPg}$ & $c^{8}$ & $\min ^{4}$ & $\%$ & $\%$ & $\%$ & $\%$ & $\%$ & $\%$ & $\%$ & $\%$ & $\%$ & $\%$ \\
\hline & & \multirow{16}{*}{0} & \multirow{16}{*}{500} & 92 & 96.3 & 99.9 & 95.8 & 98.9 & 96.3 & 99.4 & 97.8 & 99.4 & 98.9 \\
\hline \multirow[t]{3}{*}{0} & 4 & & & 97.8 & 96.9 & 98.1 & 962 & 96.8 & 97.6 & 96.4 & 95 & 95.4 & 96.6 \\
\hline & & & & 94.8 & 96.5 & 96.1 & 94.3 & 92.3 & 95 & 93.6 & 92.2 & 93.1 & 93 \\
\hline & 8 & & & 91.9 & 93.3 & 92.8 & 89.2 & 90.8 & 90.3 & 92.6 & 89 & 84.8 & 89.3 \\
\hline & 10 & & & 91.4 & 89.3 & 90.2 & 84 & 85.7 & 87.5 & 89.1 & 85.7 & 82 & 85.2 \\
\hline & 12 & & & 88.6 & 88.7 & 89.7 & 79.1 & 83.8 & 84.1 & 86 & 82.8 & 80.8 & 83.6 \\
\hline & 14 & & & 89.2 & 88.9 & 87 & 75 & 83.2 & 84.3 & 84.7 & 80.7 & 77.9 & 80.4 \\
\hline & 16 & & & 88.2 & 86.6 & 84.4 & 72.3 & 80.3 & 81.1 & 83.8 & 79.1 & 76.7 & 77 \\
\hline \multirow{4}{*}{2} & 18 & & & 85.8 & 86.3 & 82.8 & 68.8 & 77.8 & 78.7 & 81.2 & 76.6 & 75.2 & 73.8 \\
\hline & 20 & & & 83.7 & 84.3 & 80.2 & 66.4 & 74.3 & 75.3 & 77.9 & 73.8 & 73.9 & 69.4 \\
\hline & 22 & & & 81 & 82 & 78 & 63.1 & 71.7 & 72.2 & 75.1 & 70.5 & 71.9 & 64.2 \\
\hline & 24 & & & 78.5 & 78.8 & 74.3 & 59.3 & 67.3 & 68.4 & 72.3 & 66.8 & 69.5 & 58.3 \\
\hline & 26 & & & 71.8 & 73.8 & 67.3 & 55.1 & 59.9 & 59.8 & 65.1 & $6 !$ & 64 & 49.2 \\
\hline & 28 & & & 69.1 & 74.3 & 64.8 & 54.2 & 54.1 & 54 & 63.4 & 58.1 & 62.6 & 40 \\
\hline & 30 & & & 61.5 & 68.7 & 57.2 & 49.4 & 43.9 & 41.5 & 54.5 & 52.2 & 57 & 27.8 \\
\hline & 32 & & & 47.1 & 60.6 & 49.1 & 45.6 & 29 & 24.2 & 41.9 & 41.9 & 50.2 & 0 \\
\hline \multirow{4}{*}{0} & 2 & \multirow{15}{*}{ 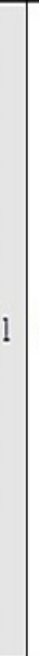 } & \multirow{16}{*}{800} & 89 & 95.1 & 88.4 & 96 & 95.7 & 95.5 & 97.4 & 88.6 & 92 & 95.7 \\
\hline & 4 & & & 94.9 & 97.1 & 96.2 & 94 & 98.4 & 97.5 & 94.5 & 97.3 & 95.9 & 98.1 \\
\hline & 6 & & & 95.2 & 94.9 & 94.9 & 96.2 & 93.4 & 93.5 & 94.5 & 92.7 & 94.1 & 94.1 \\
\hline & 8 & & & 93.2 & 93.7 & 93.7 & 91.7 & 90.6 & 90.6 & 94.2 & 90 & 90 & 93.7 \\
\hline & 10 & & & 90.8 & 91.1 & 92.9 & 87.5 & 90 & 90.6 & 92.6 & 88.8 & 86.7 & 90 \\
\hline & 12 & & & 90.9 & 89 & 89.4 & 86.2 & 88.8 & 88.9 & 91.8 & 87 & 84.6 & 87.8 \\
\hline & 14 & & & 91.2 & 88.5 & 87.6 & 86 & 88.1 & 88.9 & 91.1 & 86.7 & 83.5 & 87.9 \\
\hline & 16 & & & 90.6 & 88.3 & 87.1 & 82.9 & 86.7 & 86.7 & 90.1 & 83.7 & 82 & 85.8 \\
\hline \multirow{4}{*}{$?$} & 18 & & & 88.3 & 87.4 & 86.9 & 80.4 & 85.1 & 83.8 & 87.9 & 83 & 81 & 84.4 \\
\hline & 20 & & & 87.7 & 86.5 & 84.9 & 78.6 & 85.1 & 82.3 & 86.1 & 80.7 & 80.8 & 80.5 \\
\hline & 22 & & & 85.7 & 85.2 & 83.2 & 77.3 & 80.7 & 80.4 & 83.6 & 78.9 & 78 & 79.1 \\
\hline & 24 & & & 83.6 & 84 & 80.8 & 75.7 & 77.6 & 76.9 & 82 & 77.4 & 77.7 & 75.7 \\
\hline & 26 & & & 78.3 & 79.3 & 75.6 & 71.1 & 72.3 & 70.8 & 76.4 & 72.1 & 72.5 & 69 \\
\hline & 28 & & & 78.1 & 80.2 & 75 & 71.3 & 70 & 69.3 & 76.7 & 72.9 & 72.6 & 67.1 \\
\hline & 30 & & & 73.2 & 76.8 & 71.2 & 68.7 & 62.8 & 61.6 & 71.2 & 68.5 & 68.6 & 59.9 \\
\hline & 32 & & & 89 & 95.1 & 88.4 & 96 & 95.7 & 95.5 & 97.4 & 88.6 & 92 & 95.7 \\
\hline
\end{tabular}
range of change of the pressure $P_{t}$ and $n=500$ and 800 [rev/min] [16]. 
Table 2. General and specific logical encoding for the full range of change of the pressure $P_{t}$ and $n=1000,1500$ and 2000 $[\mathrm{rev} / \mathrm{min}][16]$

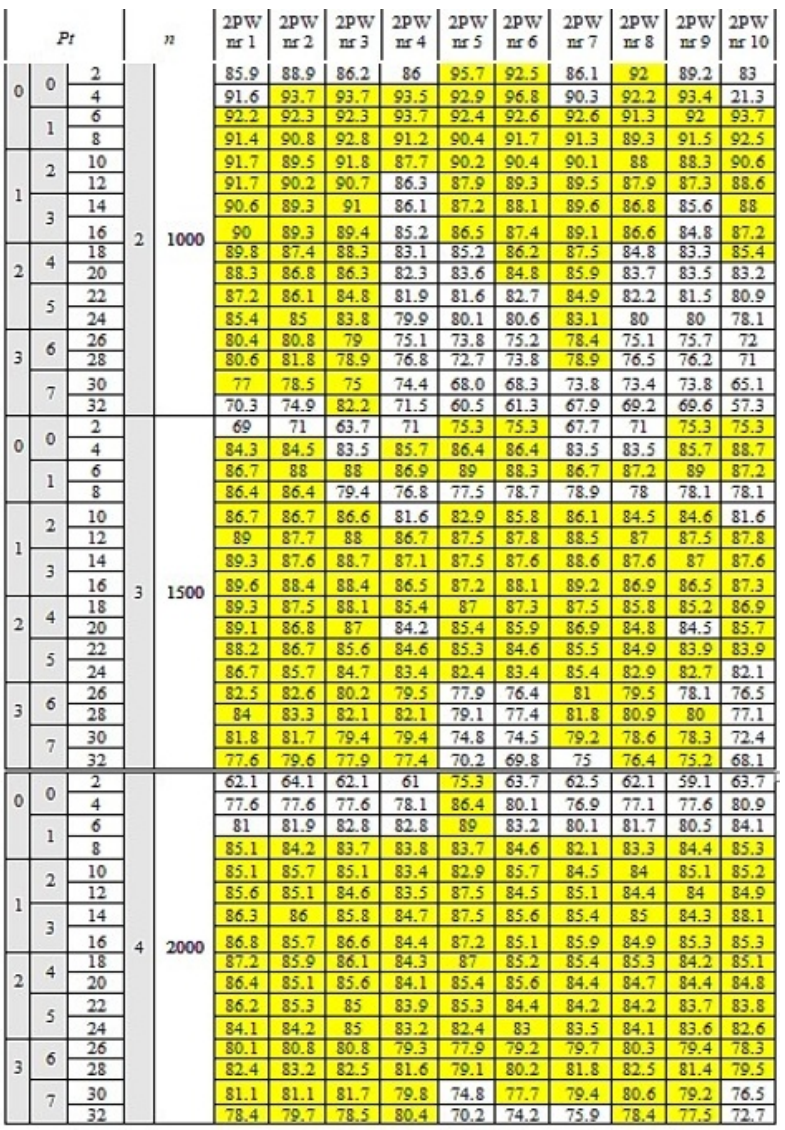

Table 3. Specific logical coding for ranges of changes $P_{t}$ and $n$, in which: a) at least 7 correspond pumps efficiency defined with a tolerance of $5 \%, b$ ) exactly 10 pumps meet prescribed performance with a tolerance of $5 \%$.

\begin{tabular}{|c|c|c|c|c|c|c|c|}
\hline \multicolumn{4}{|c|}{ a } & \multicolumn{4}{|c|}{ b } \\
\hline$P_{t}$ & $n$ & $P_{t}$ & $n$ & $P_{t}$ & $n$ & $P_{t}$ & $n$ \\
\hline 0 & 0 & 0 & 0 & 0 & 0 & 0 & 0 \\
\hline 1 & 0 & 1 & 0 & 1 & 0 & 1 & 0 \\
\hline 0 & 1 & 0 & 1 & 0 & 1 & 0 & 1 \\
\hline 1 & 1 & 1 & 1 & 1 & 1 & 1 & 1 \\
\hline 2 & 1 & 0 & 2 & 1 & 2 & 1 & 2 \\
\hline 0 & 3 & 2 & 1 & 2 & 2 & 2 & 2 \\
\hline 3 & 1 & 1 & 2 & 1 & 3 & 1 & 3 \\
\hline 4 & 1 & 0 & 3 & 2 & 3 & 2 & 3 \\
\hline 0 & 2 & 3 & 1 & 3 & 3 & 1 & 4 \\
\hline 1 & 2 & 2 & 2 & 4 & 3 & 3 & 3 \\
\hline 2 & 2 & 1 & 3 & 1 & 4 & 2 & 4 \\
\hline 3 & 2 & 4 & 1 & 2 & 4 & 4 & 3 \\
\hline 1 & 3 & 3 & 2 & 3 & 4 & 3 & 4 \\
\hline 2 & 3 & 2 & 3 & 4 & 4 & 4 & 4 \\
\hline 3 & 3 & 1 & 4 & 5 & 3 & 5 & 3 \\
\hline 4 & 3 & 3 & 3 & 5 & 4 & 5 & 4 \\
\hline 5 & 3 & 2 & 4 & 6 & 4 & 6 & 4 \\
\hline 6 & 3 & 4 & 3 & & & & \\
\hline 7 & 3 & 3 & 4 & & & & \\
\hline 1 & 4 & 5 & 3 & & & & \\
\hline 2 & 4 & 4 & 4 & & & & \\
\hline 3 & 4 & 6 & 3 & & & & \\
\hline 4 & 4 & 5 & 4 & & & & \\
\hline 5 & 4 & 7 & 3 & & & & \\
\hline 6 & 4 & 6 & 4 & & & & \\
\hline 7 & 4 & 7 & 4 & & & & \\
\hline
\end{tabular}

Table 4. General logical coding for ranges of changes $P_{t}$ and $n$, in which: a) at least 7 correspond pumps efficiency defined with a tolerance of $5 \%, b$ ) exactly 10 pumps meet prescribed performance with a tolerance of $5 \%$.

\begin{tabular}{|c|c|c|c|c|c|c|c|}
\hline \multicolumn{4}{|c|}{ a } & \multicolumn{4}{|c|}{$\mathrm{b}$} \\
\hline$P_{t}$ & $n$ & $\overline{P_{t}}$ & $n$ & $P_{t}$ & $n$ & $P_{t}$ & $n$ \\
\hline 0 & 0 & 0 & 0 & 0 & 0 & 0 & 0 \\
\hline 0 & 1 & 0 & 1 & 0 & 1 & 0 & 1 \\
\hline 1 & 1 & 1 & 1 & 0 & 2 & 0 & 2 \\
\hline 2 & 1 & 0 & 2 & 1 & 2 & 1 & 2 \\
\hline 0 & 2 & 2 & 1 & 0 & 3 & 0 & 3 \\
\hline 1 & 2 & 1 & 2 & 1 & 3 & 1 & 3 \\
\hline 0 & 3 & 0 & 3 & 2 & 3 & 0 & 4 \\
\hline 1 & 3 & 1 & 3 & 0 & 4 & 2 & 3 \\
\hline 2 & 3 & 0 & 4 & 1 & 4 & 1 & 4 \\
\hline 3 & 3 & 2 & 3 & 2 & 4 & 2 & 4 \\
\hline 0 & 4 & 1 & 4 & 3 & 4 & 3 & 4 \\
\hline 1 & 4 & 3 & 3 & & & & \\
\hline 2 & 4 & 2 & 4 & & & & \\
\hline 3 & 4 & 3 & 4 & & & & \\
\hline
\end{tabular}

Figures 6 and 7 show multiple-valued logic trees for tables 3 and 4.
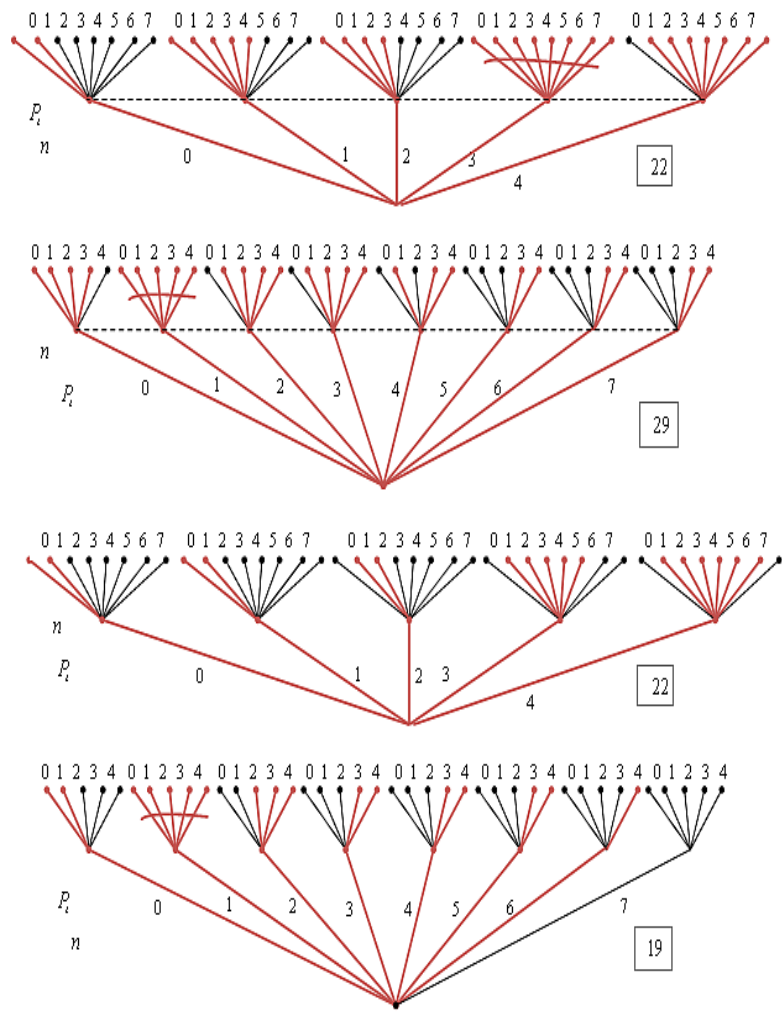

Fig. 6. Multiple- valued logic trees for Table 3. 
$20,22,24\},\{26,28,30,32\}$ for 5-value coding for valuable rotational speed $n\{500,800,1000,1500$, 2000 \} obtained higher rank of importance for $n$ to $P_{t}$. The difference is approx. $15-20 \%$, according to the contractual scale accuracy calculated on the basis of the number of branches in the relevant decision trees. Then a minimum of 7 pumps meet certain performance criteria with a tolerance of $5 \%$. If the increase decisiveness discharge pressure $P_{t}$ to 8 - value for encoding $\{0,1,2,3$, $4,5,6,7\}$ respectively, for the values $\{2,4\},\{6,8\},\{10$, $12\},\{14,16\},\{18,20\},\{22,24\},\{26,28\},\{30,32\}$ at the same speed ranges $n$ also receives a higher rank of importance for $n$ to $P_{t}$. In addition, increases the difference to $25-30 \%$, according to the contractual scale accuracy calculated the number of branches in the relevant decision trees. Then a minimum of 7 pumps meet certain performance criteria with a tolerance of $5 \%$. It is also possible for the above various decision-making valence trading to discharge pressure $P_{t}$ and identical decision valence rotational speed $n$, assuming that 10 pumps meet certain performance criteria with a tolerance of $5 \%$. Then, only in the case of 4 - value coding $\{0,1$, $2,3\}$ decision discharge pressure $P_{t}\{2,4,6,8\},\{10,12$, $14,16\},\{18,20,22,24\},\{26,28,30,32\}$ obtained higher rank of importance for $P_{t}$ to $n$, with a similar percentage difference.

The carried-out identification of the impact of the manufacturing technology on the model units showed that the important dimensions affecting the efficiency of pumps are generally repeated in all details, regardless of the analysed group. Figure 8 shows the perpendicular of the sump to the pump head in detail: pump corpus.

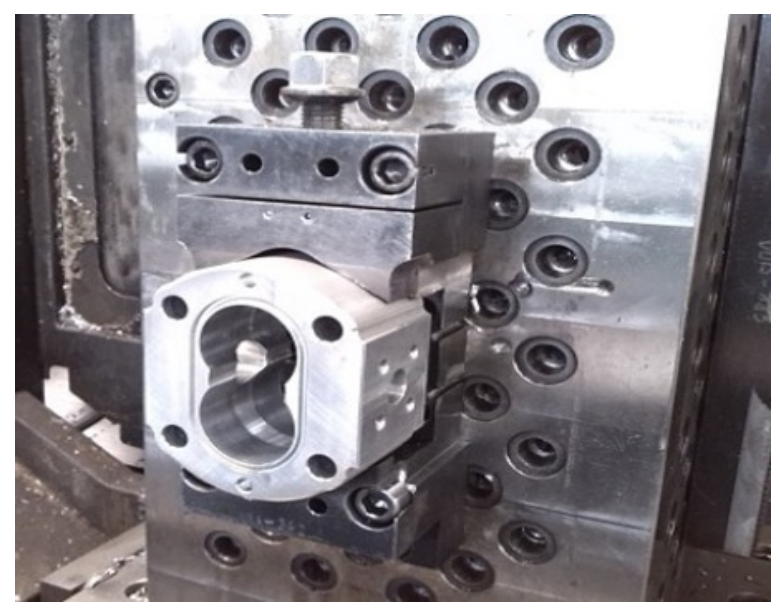

Fig. 8. The perpendicular of the sump to the pump head in detail [4].

\section{Conclusion}

Complexity of logic tables or truth tables grows exponentially in relation to the number of variables. In case of a bigger number of decision variables, there are practical geometric problems in order to extract the least and the most important data. What is more, the graphic matrix formalisation can be a computer record of parametric game trees as an adjacency matrix.

In the case of 4 - value coding $\{0,1,2,3\}$ decision discharge pressure $P_{t}\{2,4,6,8\},\{10,12,14,16\},\{18$,

\section{References}

1. A. Deptuła, P. Osiński, P., M.A.Partyka, ACME 13, 4 (2013)

2. J. Wojnowski J., Wielka Encyklopedia PWN, (Wydawnictwo Naukowe PWN, Warszawa , 2005)

3. S. Stryczek, Napęd hydrostatyczny. Tom I II. (WNT, Warszawa, 1999)

4. P. Osiński, Pompy zębate o obniżonym poziomie emisji hałasu, (Ofic. Wydaw. POLIT, Wroc, ISBN 978-83-7493-994-2, 196, 2017)

5. M. Stosiak, ACME 15, 2 (2014)

6. W. Kollek, P. Osiński, M. Stosiak, A. Wilczyński P. Cichoń,, ACME 14, 1 (2014)

7. W. Kollek Z. Kudźma , M. Stosiak, J. Mackiewicz, ACME 7, 1 (2007)

8. A. Deptuła, P. Osiński P., M. A. Partyka, Polish Maritime Research 24, 1 (2017)

9. P. Śliwiński, Polish Maritime Research 2 (2014)

10. Z. Zarzycki, S. Kudźma, Z. Kudźma, M. Stosiak, JTAM 45, 4 (2007)

11. A. Deptuła, P. Osiński, D. Kunderman, R. Włostowski, U. Radziwanowska, Archives of Acoustics 41, 2 (2016)

12. M. Stosiak, Vibration insulation of hydraulic system control components, ACME 11, 1(2011)

13. A. Glowacz, Z. Glowacz, Applied Acoustics, Part A 117 (2017) 
14. A Głowacz, Z. Głowacz, Bulletin of the Polish Academy of Sciences Technical Sciences 65, 2 (2017)

15. S. Kudźma , Z. Kudźm, JTAM 53, 3 (2015)

16. P. Osiński, W. Kollek, M. A. Partyka M. A., A. Deptuła, Identyfikacja wptywu technologii wykonania konstrukcji pomp modelowych o nowym zarysie (typ 2PW-SEW) na sprawność calkowita z uwzględnieniem logicznych struktur decyzyjnych. Raporty Wydziału Mechanicznego Politechniki Wrocławskiej, Ser. SPR no. 114, 54 -16 (2015)

17. P. Osiński, W. Kollek, M.A. Partyka, A. Deptuła, Identyfikacja wplywu technologii wykonania konstrukcji pomp modelowych o nowym zarysie (typ IPWR-SE) na sprawność calkowita $z$ uwzględnieniem logicznych struktur decyzyjnych. Raporty Wydziału Mechanicznego Politechniki Wrocławskiej, Ser. SPR no 44, 59 -17 (2015)

18. P. Osiński, W. Kollek, M.A. Partyka, A. Deptuła, Identyfikacja wplywu technologii wykonania konstrukcji pomp modelowych o nowym zarysie (typ 2PWR-SE) na sprawność calkowita $z$ uwzględnieniem logicznych struktur decyzyjnych., Raporty Wydziału Mechanicznego Politechniki Wrocławskiej, Ser. SPR no. 45, pp.50 (2015)

19. P. Osiński, W. Kollek, M.A. Partyka, A. Deptuła., Identyfikacja wplywu technologii wykonania konstrukcji pomp modelowych o nowym zarysie (typ 3PWR-SE) na sprawność catkowita $z$ uwzględnieniem logicznych struktur decyzyjnych. Raporty Wydziału Mechanicznego Politechniki Wrocławskiej, Ser. SPR no. 46, 53, pp.19 (2015)

20. A.M. Law, W. D. Kelton, Simulation Modeling and Analysis (McGraw-Hill, Boston 2000)
21. B. Filipowicz, Modele stochastyczne w badaniach operacyjnych: analiza i synteza systemów obstugi $i$ sieci kolejkowych (WNT, Warszawa 1996).

22. J R. Quinlan, Induction of Decision Trees (Machine learning 1, 1990)

23. J. R. Quinlan, R. L. Rivest R.L., Information and Computation 80 (1989)

24. D. H. Greene, D. E. Knuth D. E., Mathematics for the Analysis of Algorithms (Birkhauser, 1982)

25. J. Hertz , A. Krogh, R. G. Palmer, Wstep do teorii obliczeń neuronowych (WNT, Warszawa, 1993)

26. A. Deptuła, P. Osiński, M. A. Partyka, Proceedings of the 14th International Scientific Conference: Computer Aided Engineering, 20-23.06.2018, Polanica- Zdrój, Wydz. Mech. Polit. Wroc., (2018)

27. M.A. Partyka, Algorytm Quine'a-Mc Cluskeya minimalizacji indywidualnych cząstkowych wielowartościowych funkcji logicznych (Studia i Monografie No.109, Politechnika Opolska Oficyna Wydawnicza, Opole, 1999)

28. A. Deptuła A., P. Osiński, Proceedings of the 13th International Scientific Conference, pod redakcją: Eugeniusz Rusiński, Damian Pietrusiak, Springer International Publishing, pp. 99-107 (2017)

29. M.A. Partyka, Some remarks on the Quine - Mc Cluskey minimization algorithm of multiple-valued partial functions for design structures", 7th Inter. Cong. Log. Method. Phil. Sc. (Salzburg, Austria, 1983)

30. M. A. Partyka, The Quine-Mc Cluskey minimization algorithm of individual multiple- valued partial functions for digital control systems, 3rd Inter. Confer. Syst. Engin., Wright State (University, Dayton, USA,

1984). 